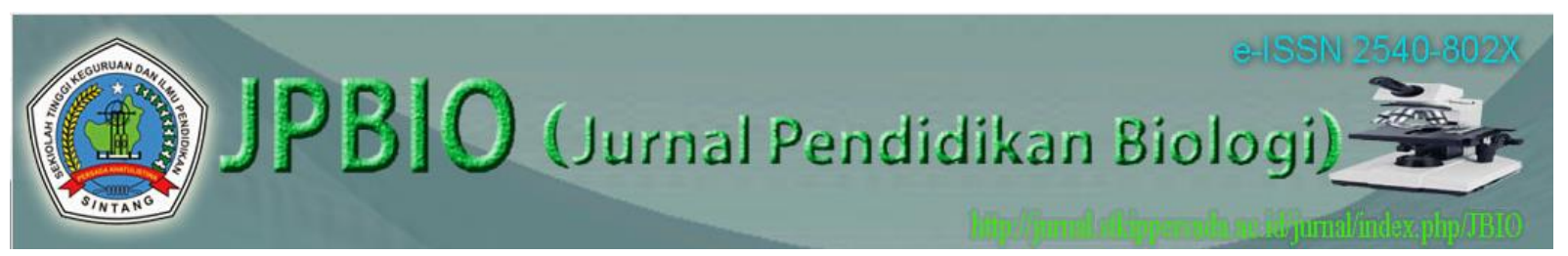

JPBIO (Jurnal Pendidikan Biologi)

Vol. 1 No. 1 November 2016 | 21 - 28

ISSN 2540-802x (Online)

DOI: http://dx.doi.org/10.31932/ JPBIO (Jurnal Pendidikan Biologi)

http://jurnal.stkippersada.ac.id/jurnal/index.php/JBIO

\title{
PENGGUNAAN MODEL PEMBELAJARAN KOOPERATIF TIPE TEAMS GAME TOURNAMENT DALAM MENINGKATKAN HASIL BELAJAR SISWA PADA MATERI PERTUMBUHAN DAN PERKEMBANGAN MAHLUK HIDUP
}

\author{
Nurhadiyanto ${ }^{1 *}$ \\ ${ }^{1}$ Program Studi Pendidikan Biologi, STKIP Persada Khatulistiwa Sintang \\ E-mail: nurhadiyanto@gmail.com*
}

Diterima: 20 April 2016

Direvisi: 23 Mei 2016

Disetujui: 12 Oktober 2016

\begin{abstract}
ABSTRAK
Tujuan penelitian ini untuk mengetahui peningkatan hasil belajar siswa kelas VIII B Sekolah Menengah Pertama Negeri 3 Sungai Tebelian melalui model pembelajaran Kooperatif Tipe Teams Game Tournament. Penelitian ini mengunakan metode penelitian kualitatif, sedangkan bentuk penelitiannya adalah penelitian tindakan kelas. Sumber data dalam penelitian ini adalah seluruh siswa kelas VIIIB serta Guru Bidang Studi Biologi Sekolah Menengah Pertama Negeri 3 Sungai Tebelian. Teknik pengumpulan data yang digunakan antara lain: teknik observasi langsung, teknik pengukuran, dan teknik komunikasi tidak langsung. Alat pengumpulan data yang digunakan yaitu: lembar observasi, hasil tes (pilihan ganda), dan lembar angket. Hasil penelitian: hasil observasi siswa siklus I pertemuan I Ya sebesar 50\% Tidak 50\%; hasil observasi siswa siklus I pertemuan II Ya $60 \%$ Tidak 40\%;rekapitulasi siklus I Y 55\% Tidak 45\%. Hasil observasi siswa siklus II pertemuan I Ya sebesar 80\% Tidak 20\%; hasil observasi siswa siklus II pertemuan II Ya 90\% Tidak 10\%;rekapitulasi siklus I Y 85\% Tidak 15\% Peningkatan hasil observasi aktivitas siswa sebesar 30\%. Aktivitas Guru siklus I pertemuan 1 Y 64,28\% Tidak 35,72\%; pertemuan II Y 78,57\% Tidak 21,43\%; siklus II pertemuan 1 Y 78,57\% Tidak 21,43\%; pertemuan II Y $85,71 \%$ Tidak $14,29 \%$. Hasil belajar siswa siklus I nilai tertinggi 86 ; nilai terendah 33; ratarata 61,48 ; ketuntasan klasikal $58,62 \%$ Hasil belajar siswa siklus II nilai tertinggi 93; nilai terendah 53; rata-rata 72,20; ketuntasan klasikal 89,65\%. Hasil angket diketahui 87,59\% siswa menjawab "Ya" dengan kereteria sangat baik, sementara yang menjawab "Tidak" $12,41 \%$ dengan kereteria kurang. Penerapan model pembelajaran Kooperatif Tipe Teams Game Tournament (TGT) dapat meningkatkan aktivitas siswa kelas VIIIB SMP N 3 Sei. Tebelian pada materi Pertumbuhan dan Perkembangan Makluk Hidup tampak dari hasil observasi.
\end{abstract}

Kata kunci: teams game tournament, hasil belajar

\section{ABSTRACT}

The purpose of this study was to determine the learning outcomes of class VIII B students of the Tebelian River 3 Middle School through the Cooperative Team Game Tournament Type learning model. This research uses qualitative research methods, while the form of research 
is classroom action research. The data sources in this study were all VIIIB grade students and Teachers in the Biology Study of Sungai Tebelian Negeri 3 Middle School. Data techniques used include: techniques, techniques, and indirect communication techniques. Data tools used are: observation, test results (multiple choice), and questionnaire sheets. Research results: student research period I I Yes at 50\% Not 50\%; student and meeting I II meeting Yes $60 \%$ No 40\%; recapitulation of cycle I Y 55\% Not 45\%. The execution of students in period II of meeting I Yes is $80 \%$ No 20\%; students and members of the second meeting cycle II Yes 90\% No 10\%; recapitulation of Y cycle I $85 \%$ Not $15 \%$ Increased student activity results by 30\%. Teacher activities first cycle meeting 1 Y 64.28\% No 35.72\%; meeting II Y 78.57\% No 21.43\%; cycle II meeting 1 Y 78.57\% No 21.43\%; meeting II $Y$ 85.71\% Not 14.29\%. Cycle I student learning outcomes Highest score 86; lowest value 33; average 61.48; classical completeness 58.62\% Cycle II student learning outcomes Highest score 93; lowest value 53; average of 72.20; classical completeness $89.65 \%$. Questionnaire results Looking at $87.59 \%$ of students answered "Yes" with a very good cafeteria, while those who answered "No" $12.41 \%$ with less cafeteria. The application of the Cooperative Team Game Tournament Type (TGT) learning model can improve the activities of VIII grade $3 \mathrm{~N}$ Sei students. Tebelian on material Growth and Growth of Living Beings of results.

\section{Keywords: game tournament teams, learning outcomes}

\section{PENDAHULUAN}

Pendidikan merupakan proses budaya untuk meningkatkan harkat dan martabat manusia yang berlangsung seumur hidup pendidikan dapat dilaksanakan di lingkungan keluarga, sekolah dan masyarakat. Oleh karena itu, pendidikan dimaknai sebagai proses mengubah tingkah laku anak didik agar menjadi manusia dewasa yang mampu hidup mandiri sebagai anggota masyarakat dalam lingkungan alam sekitar dimana individu itu berada.

Pendidikan tidak hanya mencakup pengembangan intelektualitas saja, tetapi lebih ditekankan pada proses pembinaan kepribadian anak didik secara menyeluruh sehingga anak menjadi lebih dewasa (Sagala, 2005: 3). Dalam Dictionary of Psychology (1972), pendidikan diartikan sebagai "the institutional procedures which are employed in accomplishing the development of knowledge, habits, attitudes, etc". Jadi pendidikan berarti tahapan kegiatan yang bersifat kelembagaan (seperti sekolah dan madrasah) yang dipergunakan untuk menyempurnakan perkembangan individu dalam menguasai pengetahuan, kebiasaan, sikap dan sebagainya (Syah, 2006: 11).

Biologi sebagai salah satu mata pelajaran di sekolah dinilai cukup memegang peranan penting dalam membentuk siswa menjadi berkualitas, karena biologi merupakan suatu sarana berpikir untuk mengkaji sesuatu secara logis dan sistematis. Oleh karena itu peningkatan mutu pendidikan biologi sangat diperlukan. Dalam pembelajaran di sekolah, biologi merupakan salah satu mata pelajaran yang masih dianggap sulit dipahami oleh siswa. Oleh karena itu, pemerintah berupaya semaksimal mungkin mengadakan perbaikan dan penyempurnaan di bidang pendidikan terutama dalam mata pelajaran biologi. Sebagai langkah antisipasi maka pendidikan banyak diarahkan pada panataan proses pembelajaran, pengunaan, dan pemilihan metode serta media secara tepat.

Pembelajaran biologi di sekolah masih menggunakan model atau metode pembelajaran yang monoton seperti metode ceramah, sementara siswa duduk secara pasif menerima informasi pengetahuan dan keterampilan. Pengunaan model ini ditengarai menyebabkan kegagalan siswa dalam memahami mata pelajaran. Kemungkinan lain kegagalan guru dalam menyampaikan materi disebabkan saat proses pembelajaran guru kurang membangkitkan perhatian dan aktivitas peserta didik dalam pembelajaran Biologi. Hal ini diduga menyebabkan hasil belajar atau tujuan pembelajaran tidak maksimal, karena guru kurang tepat memilih metode dan model pembelajaran yang sesuai.

Berdasarkan hasil nilai MID semester (lampiran) pada mata pelajaran biologi siswa kelas VIII B Sekolah Menengah Pertama Negeri 3 Sungai Tebelian, hasil belajar siswa kelas VIII B khususnya untuk mata pelajaran biologi masih rendah karena terdapat $55 \%$ siswa 
masih memperoleh nilai di bawah Kriteria Ketuntasan Minimal (KKM) yang ditetapkan sekolah tersebut yaitu 60. Dari hasil pengamatan pembelajaran Biologi di Sekolah Menengah Pertama Negeri 3 Sungai Tebelian ditemukan beberapa kelemahan, diantaranya adalah hasil belajar siswa yang masih rendah, menurut guru mata pelajaran biologi hal tersebut dipengaruhi oleh beberapa faktor yaitu: keaktifan siswa kelas VIII B dalam mengikuti pembelajaran belum tampak, siswa jarang mengajukan pertanyaan meskipun guru memberikan kesempatan bertanya tentang hal-hal yang belum dipahami; proses pembelajaran didominasi siswa tertentu; siswa kurang tertarik dengan cara guru menyampaikan materi; serta sebagian besar siswa kurang termotivasi untuk belajar. Faktor lain yang berhasil di klarifikasi adalah siswa cenderung sering terlihat bermain ketika guru yang bersangkutan sedang menjelaskan materi pelajaran di depan kelas.

Melihat fenomena tersebut, maka perlu diterapkan suatu sistem pembelajaran yang melibatkan peran siswa secara aktif dalam kegiatan belajar mengajar serta dapat mengambil perhatian siswa-siswi yang kurang memperhatikan gurunya saat pelajaran berlangsung. Salah satu model pembelajaran yang melibatkan peran siswa secara aktif adalah model pembelajaran kooperatif.

Model pembelajaran kooperatif adalah model pembelajaran yang bersifat keaktifan dimana siswa dapat mengemukakan pikirannya, saling bertukar pendapat, saling bekerja sama, dan membantu kesiapan siswa dalam menerima pelajaran serta saling membantu jika ada teman dalam kelompoknya yang mengalami kesulitan. Hal ini dapat meningkatkan motivasi belajar siswa untuk memahami dan menguasai materi pelajaran biologi sehingga akan dapat meningkatkan hasil belajar siswa. Salah satu model pembelajaran kooperatif dimana siswa diajak turut serta dalam proses pembelajaran untuk mengatasi masalah yaitu model pembelajaran Teams Game Tournament (TGT) di kelas VIII B.

Model pembelajaran (TGT) ini menyajikan pelajaran dengan cara siswa dibentuk dalam kelompok yang beranggotakan 4-5 orang yang berbeda-beda tingkat kemampuan, jenis kelamin, dan latar belakang etniknya. Setiap peserta didik mengerjakan tugas yang diberikan secara bersama-sama dengan anggota kelompoknya, jika dari anggota kelompok tidak mengerti dengan tugasnya, maka kelompok lain bertanggung jawab untuk memberikan jawaban, dan pada akhirnya untuk memastikan seluruh anggota kelompok telah menguasai pelajaran. Seluruh siswa diberikan permainan akademik, permainan ini dapat menumbuhkan tanggung jawab, kerja sama, persaingan sehat dan keterlibatan belajar siswa. Pada tahap terakhir akan diberikan penghargaan untuk setiap kelompok, sehingga dengan demikian setiap anggota kelompok merasa bertanggung jawab terhadap kelompoknya.

Penerapan model pembelajaran kooperatif tipe Teams Game Tournament (TGT) dalam pembelajaran biologi ini melibatkan siswa untuk berperan aktif dengan bimbingan guru sehingga diharapkan hasil belajar yang diinginkan dapat tercapai. Oleh karena itu, dengan Skripsi berjudul "Pengunaan Model Pembelajaran Kooperatif Tipe Teams Games Tournament (TGT) Untuk Meningkatkan Hasil Belajar Siswa Dikelas VIII B Pada Materi Pertumbuhan Dan Perkembangan Makhluk Hidup sekolah Menengah Pertama Negeri 3 Sei. Tebelian Tahun Pelajaran 2013/2014" siswa dapat memperololeh hasil belajar biologi yang diharapkan yaitu memenuhi nilai KKM, selain itu siswa mempunyai keterampilan untuk mengembangkan materi yang telah di terima dalam kehidupan sehari-hari.

\section{METODE PENELITIAN}

Menurut Arikunto (2006: 160), "Metode penelitian adalah cara yang digunakan oleh peneliti dalam mengumpulkan data penelitian". Dalam penelitian ini, tujuan yang hendak dicapai yaitu untuk mengetahui hasil belajar siswa kelas VIII B pada mata pelajaran biologi di Sekolah Menengah Pertama Negeri 3 Sei. Tebelian dengan menggunakan Model pembelajaran kooperatif tipe Teams Game Tournament. Metode penelitian yang digunakan dalam penelitian ini yaitu metode kualitatif.

Penelitian ini berbentuk penelitian tindakan (Action research). Penelitian tindakan bertujuan untuk memperbaiki pembelajaran. Perbaikan dilakukan secara bertahap dan terus-menerus, selama penelitian dilakukan (Wardhani, 2007: 17). Model penelitian tindakan 
kelas, secara garis besar terdapat empat tahapan, yaitu: perencanaan, pelaksanaan, pengamatan, dan refleksi.

\section{HASIL DAN PEMBAHASAN PENELITIAN}

a. Hasil dan Pembahasan Lembar Observasi

Lembar observasi terdiri dari lembar observasi guru dan lembar observasi siswa. Peneliti menggunakan lembar observasi yang berisi aspek-aspek yang diamati berdasarkan pada keterlaksanaan pembelajaran melalui model TGT.

\section{1) Aktivitas Siswa Siklus I}

Hasil observasi dilakukan oleh observer. Dari hasil observasi yang didapatkan setiap kali pertemuan pada proses pembelajaran. Aktivitas belajar siswa pada siklus I belum memuaskan dengan hasil $50 \%$ hanya di kategorikan kurang, sehingga peneliti melakukan observasi pada masalah-masalah yang harus diperbaiki, setelah melakukan perbaikan pada pertemuan kedua pada proses pembelajaran aktivitas siswa mulai terlihat meningkat dari pertemuan pertama yaitu meningkat menjadi $60 \%$. Untuk melihat lebih jelas hasil lembar observasi aktivitas siswa siklus I dapat dilihat pada (halaman 151). Rekapitulasi hasil observasi siswa siklus I dapat dilihat pada Tabel 4.2 berikut ini.

Tabel 1. Hasil Observasi Siswa Siklus I

\begin{tabular}{ccc}
\hline \multirow{2}{*}{ Siklus I } & \multicolumn{2}{c}{ Hasil Pengamatan } \\
\cline { 2 - 3 } & Ya & Tidak \\
\hline Pertemuan 1 & $50 \%$ & $50 \%$ \\
\hline Pertemuan 2 & $60 \%$ & $40 \%$ \\
\hline Rekapitulasi & $55 \%$ & $45 \%$ \\
\hline
\end{tabular}

\section{2) Aktivitas Siswa Siklus II}

Aktivitas belajar siswa pada siklus II mengalami peningkatan yang cukup tinggi, dapat dilihat pada Tabel 4.3 berikut ini.

Tabel 2. Hasil Observasi Siswa Siklus II

\begin{tabular}{ccc}
\hline \multirow{2}{*}{ Siklus II } & \multicolumn{2}{c}{ Hasil Pengamatan } \\
\cline { 2 - 3 } & Ya & Tidak \\
\hline Pertemuan 1 & $80 \%$ & $20 \%$ \\
\hline Pertemuan 2 & $90 \%$ & $10 \%$ \\
\hline Rekapitulasi & $85 \%$ & $15 \%$ \\
\hline
\end{tabular}

Berdasarkan Tabel 4.3 membuktikan adanya perubahan yang signifikan dibandingkan dengan siklus I, yaitu nilai hasil observasi meningkat menjadi $90 \%$. Perubahan yang menunjukkan adanya peningkatan pada siklus II tersebut dikarenakan siswa sudah terbiasa dengan kegiatan pembelajaran dengan model TGT dan juga guru menyampaikan motivasi dikaitkan dengan lingkungan sehingga siswa mudah untuk memahami. "Konsep-konsep Biologi akan berhasil jika dipelajari dalam tahap-tahap tertentu, penyajian (multiple embodiment), permainan (games), pertandingan (tournament), dan penghargaan". (Ruseffendi, 1992:125-127).Berdasarkan aktifitas siswa di siklus I dan siklus II sebesar 30\% peningkatan tersebut sangat signifikan maka peneliti tdiak melanjutkan ke siklus selanjutnya.

\section{3) Aktivitas Peneliti}

Aktivitas peneliti sebagai pengajar digunakan untuk melihat proses penerapan Model Teams Game Tournament (TGT). Dari hasil pengamatan yang dilakukan observer pada setiap siklus, model pembelajaran Teams Game Tournament (TGT) telah disampaikan dengan baik meskipun masih ada beberapa aspek yang belum terpenuhi pada setiap siklus. Perbandingan hasil analisis lembar observasi peneliti dapat dilihat pada Tabel 4.4 berikut: 
Tabel 3 Persentase Aktivitas Guru

\begin{tabular}{ccccc}
\hline \multirow{2}{*}{ PERTEMUAN } & \multicolumn{2}{c}{ SIKLUS I } & \multicolumn{2}{c}{ SIKLUS II } \\
\cline { 2 - 5 } & Y\% & T\% & Y\% & T\% \\
\hline 1 & $64,28 \%$ & $35,72 \%$ & $78,57 \%$ & $21,43 \%$ \\
\hline 2 & $78,57 \%$ & $21,43 \%$ & $85,71 \%$ & $14,29 \%$ \\
\hline
\end{tabular}

\section{b. Hasil Belajar Siswa}

\section{1) Nilai Siswa Sebelum Penelitian}

Nilai siswa kelas VIII B SMP N 3 Sei. Tebelian sebelum dilakukan tindakan yang berupa pembelajaran dengan menerapkan model pembelajaran TGT dapat dilihat dari hasil belajar pada mata pelajaran biologi sehingga diketahui bahwa dari 29 siswa nilai rata-rata kelasnya adalah 54,13 nilai terendah 33 dan nilai tertinggi 80 , hasil nilai prasiklus dapat dilihat pada (halaman 155). Untuk nilai rata-rata kelas adalah 54,13 kriteria ini masih dibawah standar KKM yakni 60 dan siswa dikatakan tidak tuntas. Dari 29 siswa yang sudah mencapai standar ketuntasan belajar berjumlah 11 siswa atau 38\% sedangkan yang tidak tuntas berjumlah 18 siswa atau 62,06\%. Dari Tabel 4.5 di bawah ini dapat dilihat rekapitulasi nilai siswa sebelum dilaksanakan tindakan.

Tabel 4. Rekapitulasi Nilai Siswa Sebelum Penelitian

\begin{tabular}{cc}
\hline Hasil Tes & Pra Siklus \\
\hline Nilai Tertinggi & $\mathbf{8 0}$ \\
\hline Nilai Terendah & $\mathbf{3 3}$ \\
\hline Rata-rata & $\mathbf{5 4 , 1 3}$ \\
\hline Ketuntasan Klasikal & $\mathbf{3 8 \%}$ \\
\hline
\end{tabular}

\section{2) Nilai Siswa Sesudah Tindakan}

Hasil belajar siswa kelas VIII B SMP N 3 Sei. Tebelian setelah dilakukan tindakan siklus I terjadi peningkatan yaitu sebesar $20,62 \%$ dari $38 \%$ pada prasiklus menjadi $58,62 \%$ pada siklus I, kemudian pada siklus II mengalami peningkatan $31,03 \%$ dari $58,6 \%$ pada siklus I menjadi $89,65 \%$ di siklus II yaitu terdapat 26 siswa yang tuntas. Rekapitulasi ketuntasan belajar siswa pada siklus I dan siklus II dapat dilihat pada Tabel 4.6 berikut:

Tabel 5. Rekapitulasi Nilai Siklus I dan Siklus II

\begin{tabular}{ccc}
\hline Hasil Tes & Siklus I & Siklus II \\
\hline Nilai Tertinggi & 86 & 93 \\
\hline Nilai Terendah & 33 & 53 \\
\hline Rata-rata & 61,48 & 72,20 \\
\hline Ketuntasan Klasikal & $58,62 \%$ & $89,65 \%$ \\
\hline
\end{tabular}

Berdasarkan Tabel 4.6 terjadi peningkatan hasil belajar yang signifikan pada siswa kelas VIII B setelah diterapkannya model pembelajaran Teams Game Tournament (TGT). Jika dibandingkan dengan sebelum dilakukan penelitian, terjadi peningkatan nilai rata-,rata siswa dan ketuntasan belajar siswa pada siklus I dan siklus II. Nilai tertinggi siswa pada postest siklus I yaitu 86 , nilai terendah 33 , sementara nilai rata-rata siswa yaitu 61,48 , untuk ketuntasan klasikal mencapai 58,62, lebih jelasnya dapat dilihat pada lampiran 24 (halaman 157). Meskipun sudah terjadi peningkatan hasil belajar siswa dengan nilai sebelumnya namun tetap dilanjutkan ke siklus berikutnya, karena peneliti merasa masih kurang puas dengan hasil yang di peroleh.

Setelah dilakukan tindakan pada siklus II, terjadi peningkatan hasil belajar siswa, yakni dari 29 siswa yang mengikuti tes, hanya 3 atau 10,34\% orang siswa yang nilainya masih dibawah KKM dengan persentase ketuntasan klasikal mencapai $89,65 \%$, untuk nilai terendah yaitu 53 sedangkan nilai tertinggi 93 , dan nilai rata-rata kelas 72,20 , dengan rincian nilai dapat dilihat pada lampiran 24 (halaman 157). Dengan hasil ini peneliti merasa puas 
dan ketuntasan klasikal sudah mencapai standar yang ditetapkan yaitu $85 \%$ sehingga peneliti tidak melanjutkan ke siklus berikutnya.

\section{c. Hasil dan Pembahasan Angket Respon Siswa}

Pada penelitian ini, respon atau tanggapan siswa terhadap pada materi Pertumbuhan dan Perkembangan Mahluk Hidup menggunakan model pembelajaran kooperatif tipe teams Games tournaments. Angket yang berisi 15 pertanyaan diberikan kepada 29 orang siswa pada akhir siklus untuk digunakan sebagai salah satu bahan refleksi bagi peneliti.

Soal angket pertama adalah Apakah sebelum memulai pembelajaran Anda selalu membaca terlebih dahulu materi yang diajarkan. 68,97\% atau 20 siswa menyatakan bahwa selalu membaca terlebih dahulu materi yang di ajarkan.31,03\% atau 9 siswa menyatakan tidak membaca terlebih dahulu materi yang di ajarkan

Soal angket kedua adalah Apakah menurut Anda melakukan persiapan sebelum memulai pelajaran merupakan hal yang penting. 82,75\% atau 24 siswa menyatakan penting melakukan persiapan sebelum memulai pelajaran. 17,24\% atau 5 siswa menyatakan tidak melakukan persiapan sebelum memulai pelajaran

Soal angket ketiga adalah Apakah Anda menyukai pokok bahasan pertumbuhan dan perkembangan makhluk hidup. $82,75 \%$ atau 24 siswa menyatakan menyukai pokok bahasan pertumbuhan dan perkembangan makhluk hidup. 17, $24 \%$ atau 5 siswa menyatakan tidak menyukai pokok bahasan pertumbuhan dan perkembangan makhluk hidup.

Soal angket keempat adalah Menurut Anda apakah pokok bahasan pertumbuhan dan perkembangan makhluk hidup merupakan materi yang penting dan bermanfaat.93,10\% atau 27 siswa menyatakan pertumbuhan dan perkembangan makhluk hidup merupakan materi yang penting dan bermanfaat. 6,90\% atau 2 menyatakan pertumbuhan dan perkembangan makhluk hidup merupakan materi yang tidak penting dan bermanfaat.

Soal angket kelima adalah Apakah pokok bahasan pertumbuhan dan perkembangan makhluk hidup merupakan pokok bahasan yang sulit dipelajari. 86,20\% atau 25 siswa menyatakan pertumbuhan dan perkembangan makhluk hidup merupakan pokok bahasan yang sulit dipelajari. $13,80 \%$ atau 4 menyatakan pertumbuhan dan perkembangan makhluk hidup merupakan pokok bahasan yang tidak sulit dipelajari .

Soal angket keenam adalah Apakah Anda merasa memiliki tanggung jawab dalam diskusi kelompok dan dalam mengumpulkan skor kelompok. 82,75\% atau 24 siswa menyatakan merasa memiliki tanggung jawab dalam diskusi kelompok dan dalam mengumpulkan skor kelompok. $17,24 \%$ atau 5 siswa menyatakan tidak merasa memiliki tanggung jawab dalam diskusi kelompok dan dalam mengumpulkan skor kelompok.

Soal angket ketujuh adalah Apakah kamu lebih menyukai pokok bahasan pertumbuhan dan perkembangan makhluk hidup dengan menerapkan model pembelajaran Teams Game tournament. 96,55\% atau 28 siswa menyatakan menyukai pokok bahasan pertumbuhan dan perkembangan makhluk hidup dengan menerapkan model pembelajaran Teams Game tournament. 3,44\% atau 1 siswa menyatakan tidak menyukai pokok bahasan pertumbuhan dan perkembangan makhluk hidup dengan menerapkan model pembelajaran Teams Game tournament.

Soal angket kedelapan adalah Apakah kamu mudah memahami materi yang disampaikan guru dengan model Teams Game Tournamen. 93,10\% atau 27 siswa menyatakan mudah memahami materi yang disampaikan guru dengan model Teams Game Tournamen. 6,90\% atau 2 siswa menyatakan tidak mudah memahami materi yang disampaikan guru dengan model Teams Game Tournamen.

Soal angket kesembilan adalah Apakah kamu menjadi lebih senang dalam mempelajari materi biologi dengan model Teams Game Tournamen. 96,55\% atau 28 siswa menyatakan menjadi lebih senang dalam mempelajari materi biologi dengan model Teams Game Tournamen. 3,44\% atau 1 siswa menyatakan tidak senang dalam mempelajari materi biologi dengan model Teams Game Tournamen.

Soal angket kesepuluh adalah Apakah dengan model pembelajaran Teams Game Tournamen lebih memudahkan kamu dalam memahami konsep-konsep pertumbuhan dan 
perkembangan makhluk hidup. 86,20\% atau 25 siswa menyatakan model pembelajaran Teams Game Tournamen lebih memudahkan kamu dalam memahami konsep-konsep pertumbuhan dan perkembangan makhluk hidup. 13,80\% atau 4 siswa menyatakan model pembelajaran Teams Game Tournamen tidak memudahkan dalam memahami konsepkonsep pertumbuhan dan perkembangan makhluk hidup.

Soal angket kesebelas adalah Apakah dengan mengajukan pertanyaan dalam kegiatan pembelajaran membuat kamu lebih aktif dalam mengikuti pelajaran. $82,75 \%$ atau 24 siswa menyatakan mengajukan pertanyaan dalam kegiatan pembelajaran membuat kami lebih aktif dalam mengikuti pelajaran. 17,24 atau 5 siswa menyatakan mengajukan pertanyaan dalam kegiatan pembelajaran tidak membuat lebih aktif dalam mengikuti pelajaran.

Soal Angket keduabelas adalah Apakah dengan penggunaan model pembelajaaran Teams Game Tournamen membuat hasil belajar kamu lebih baik. 93,10\% atau 27 siswa menyatakan penggunaan model pembelajaaran Teams Game Tournamen membuat hasil belajar lebih baik. 6,90\% atau 2 siswa menyatakan penggunaan model pembelajaaran Teams Game Tournamen tidak membuat hasil belajar lebih baik.

Soal angket ketigabelas adalah Apakah kegiatan belajar kali ini lebih menarik dibanding dengan kegiatan belajar sebelumnya. 93,10\% atau 27 siswa menyatakan kegiatan belajar kali ini lebih menarik dibanding dengan kegiatan belajar sebelumnya. 6,90\% atau 2 siswa menyatakan kegiatan belajar kali ini tidak menarik dibanding dengan kegiatan belajar sebelumnya.

Soal angket keempatbelas adalah Apakah kamu merasa termotivasi pada saat mengikuti pembelajaran dengan penggunaan model Teams Game Tournamen. 89,65\% atau 26 siswa menyatakan merasa termotivasi pada saat mengikuti pembelajaran dengan penggunaan model Teams Game Tournamen. 10,34\% atau 3 siswa menyatakan tidak termotivasi pada saat mengikuti pembelajaran dengan penggunaan model Teams Game Tournaments.

Soal angket terakhir adalah Apakah model pembelajaran Teams Game Tournaments membantu kamu dalam menuangkan ide-ide atau pendapat. 86,20\% atau 25 siswa menyatakan model pembelajaran Teams Game Tournaments membantu dalam menuangkan ide-ide atau pendapat. $13,80 \%$ atau 4 siswa menyatakan model pembelajaran Teams Game Tournaments tidak membantu dalam menuangkan ide-ide atau pendapat.

Dengan demikian dapat disimpulkan bahwa apabila pembelajaran menggunakan model pembelajaran kooperatif tipe teams games tournaments dilaksanakan dengan baik dan menggunakan strategi yang tepat untuk menarik minat siswa terhadap pembelajaran, maka pembelajaran tersebut akan mendapat respons positif dari sebagian besar siswa.

Tabel 6. Rekapitulasi Nilai Angket Respon Siswa

\begin{tabular}{ccc}
\hline Ketuntasan & Persentase & Kriteria \\
\hline YA & $87,59 \%$ & Sangat Baik \\
\hline TIDAK & $12,41 \%$ & Kurang \\
\hline
\end{tabular}

Berdasarkan hasil angket yag telah direkapitulasi diketahui $87,59 \%$ siswa SMP N 3 Sei. Tebelian kelas VIII B menjawab "YA" dengan kriteria sangat baik, sementara yang menjawab "TIDAK" persentasenya $12,41 \%$ dengan kriteria kurang, lebih lengkapnya dapat dilihat pada (Hal 161) dengan demikian hampir semua siswa kelas VIII B setuju dengan penerapan model pembelajaran TGT.

\section{SIMPULAN}

Secara garis besar hasil perbaikan pembelajaran dengan menggunakan model pembelajaran Teams Game Tournament (TGT) di SMP N 3 Sei. Tebelian pada kelas VIII B dapat ditarik kesimpulan sebagai berikut: (1) Penerapan model pembelajaran Teams Game Tournament (TGT) dapat meningkatkan aktivitas siswa kelas VIII B SMP N 3 Sei. Tebelian pada materi pertumbuhan dan perkembangan makhluk hidup, hal ini tampak dari hasil 
observasi siswa pada siklus I yaitu pertemuan pertama Ya 50\% Tidak 50\%. Pertemuan kedua meningkat menjadi Ya 60\% Tidak 40\%, dan rekapitulasi Ya 55\% Tidak 45\%. Sementara pada siklus II yaitu pertemuan pertama Ya $80 \%$ Tidak $20 \%$, dan pertemuan kedua menjadi Ya90\% Tidak 10\%, rekapitulasi Ya 85\% Tidak 15\%. Berdasarkan rekapitulasi aktivitas siswa siklus I sebesar Ya 55\% dan siklus II sebesar Ya 85\%, maka peningkatan aktivitas siswa sebesar $30 \%$. Sementara hasil dari aktivitas guru siklus I pertemuan I Ya 64,28\% Tidak 35,72\%, dan pertemuan II Ya 78,57\% Tidak 21,43\%. Aktivitas guru siklus II pertemuan I Ya 78,57\% Tidak 21,43\%, dan pertemuan II Ya 85,71\% Tidak 14,29\%; (2) Hasil belajar siswa setelah diterapkan model pembelajaran Teams Game Tournament (TGT) pada siklus I diperoleh nilai tertinggi sebesar 86 , nilai terendah 33 , rata-rata 61,48 dengan ketuntasan klasikal sebesar $58,62 \%$, dan siklus II diperoleh nilai tertinggi sebesar 93 , nilai terendah 53, rata-rata 72,20 dengan ketuntasan klasikal sebesar $89,65 \%$. Dengan hal ini peneliti merasa puas dan ketuntasan klasikal sudah mencapai standar yang di tetapkan yaitu $85 \%$ sehingga peneliti tidak melanjutkan ke siklus yang berikutnya; (3) Respon siswa terhadap penerapan model pembelajaran Teams Game Tournament (TGT) berkategori sangat baik, siswa yang menjawab setuju berjumlah $87,59 \%$ dan yang menjawab tidak setuju berjumlah $12,41 \%$.

\section{REFERENSI}

Arikunto, S. (2012). Penelitian Tindakan Kelas. Jakarta: Bumi Aksara.

Bungin, B. (2011). Metodotologi Penelitian Kuantitatif. Jakarta: Kencana Persada Media Group

Campbell, Reece, Mitchell. (2000). Biologi, Fifth Edition. Jakarta: Penerbit Erlangga. 